\title{
BEBERAPA JENIS ALAT TANGKAP KEPITING BAKAU (Scylla spp.) DI DESA MAYANGAN PANTAI UTARA JAWA
}

\author{
Soleh Romdon \\ Teknisi Litkayasa pada Loka Riset Pemacuan Stok Ikan, Jatiluhur-Purwakarta \\ Teregristasi I tanggal: 23 Juli 2008; Diterima setelah perbaikan tanggal: 24 Juli 2008; \\ Disetujui terbit tanggal: 24 Juli 2008
}

\section{PENDAHULUAN}

Desa Mayangan secara administratif terletak di Kecamatan Legon Kulon Kabupaten Subang (Pantura Jawa). Perairan pantai tersebut terdapat mangrove dengan luas yang pada awalnya 290 ha, namun yang tersisa sekarang tinggal 100 ha (Syam et al., 2007). Hutan mangrove merupakan habitat berbagai biota laut dan salah satunya adalah kepiting bakau (Scylla spp.).

Kepiting bakau merupakan salah satu komoditas perikanan yang mempunyai nilai ekonomis penting di Indonesia (Sulistiono et al., 1994). Demikian juga di Desa Mayangan, kepiting bakau ini telah lama diperdagangkan baik dalam bentuk kepiting dewasa hasil tangkapan maupun setelah pemeliharan (penggemukan).

Permintaan komoditas ini sangat tinggi karena rasa yang lezat dan mengandung protein tinggi. Dalam upaya untuk memenuhi kebutuhan pasokan pasar lokal maupun ekspor, nelayan setempat berbagai cara menggunakan beberapa jenis alat tangkap untuk menangkap kepiting Bakau. Daerah penangkapan kepiting bakau meliputi seluruh lahan hutan bakau yang ada di wilayah pesisir pantai Desa Mayangan, khususnya daerah pertambakan, dan di aliran sungai. Pengamatan ini bertujuan untuk mengetahui beberapa jenis alat tangkap yang digunakan oleh nelayan Desa Mayangan.

\section{BAHAN DAN METODE}

\section{Waktu dan Lokasi}

Pengamatan ini dilakukan di Desa Mayangan, Kabupaten Subang pada beberapa lokasi penangkapan kepiting bakau (Scylla spp.) (Gambar 1). Pengamatan dilakukan pada bulan Pebruari, Mei, Juni, dan Desember 2007.

Metode yang digunakan melalui pengamatan langsung di lapangan dan wawancara dengan nelayan setempat. Alat yang digunakan pada pengamatan ini adalah caliper dan penggaris.

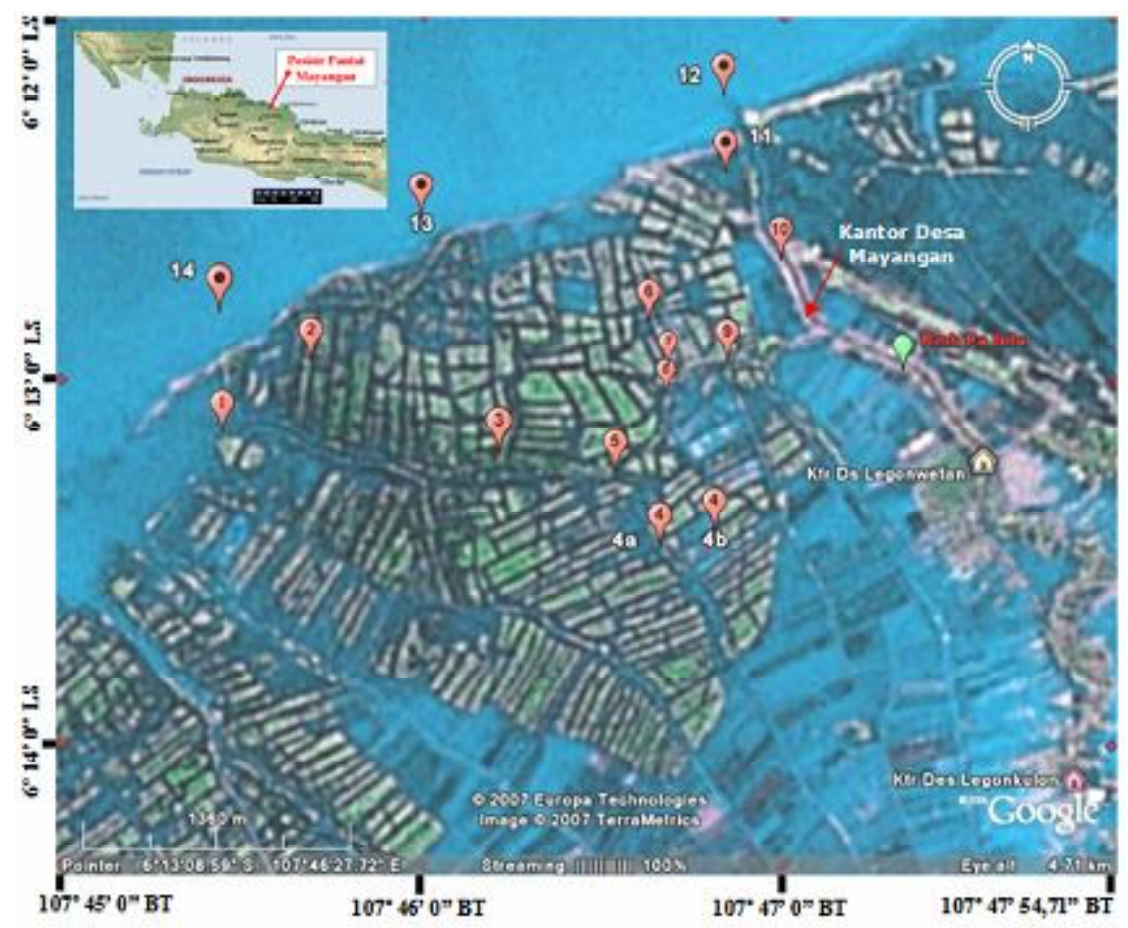

Gambar 1. Peta lokasi penangkapan kepiting bakau (Scylla spp.) di Desa Mayangan. 


\section{POKOK BAHASAN}

Penangkapan kepiting di Desa Mayangan dilakukan sepanjang waktu, baik siang maupun malam, tergantung jenis alat tangkap yang digunakan. Alat tangkap badong dan wadong dapat dilakukan setiap saat karena bersifat pasif. Sedangkan alat tangkap pancing atau caduk dan bangkol, beroperasi pada siang hari, namun apabila hendak digunakan pada malam hari dilengkapi dengan penerangan (lampu atau obor).

\section{Alat Tangkap Badong dan Wadong}

Badong merupakan jenis alat tangkap sejenis bubu yang awalnya berbahan dasar bambu yang di anyam. Namun, dalam perkembangan sebagian sudah menggunakan kerangka dasar kawat besi dan jaring atau lebih dikenal dengan sebutan bubu lipat (wadong). Alat tangkap badong dilengkapi dengan 2 pintu pada sisi kanan dan kiri, sebagai pintu masuk kepiting, serta sebuah kunci pengait di bagian atas. Pada umumnya badong yang terbuat dari bambu berbentuk silinder dengan panjang $\pm 50 \mathrm{~cm}$ dengan diameter pintu masuk $\pm 20 \mathrm{~cm}$ (Gambar 2). Sedangkan wadong adalah alat tangkap yang terbuat dari besi berbentuk kotak persegí panjang dengan ukuran $80 \times 40 \times 20 \mathrm{~cm}$ (Gambar 3). Besi yang digunakan sebagai kerangka dasar berdiameter $4 \mathrm{~mm}$, dan menggunakan jaring dengan ukuran mata jaring 1,25 inci. Penggunaan alat tangkap dilakukan dengan meletakkan di dasar perairan dan diberi umpan ikan kecil. Sebagian besar nelayan memeriksa dan memindahkan lokasi penempatan badong dan wadong 2 kali dalam sehari yaitu pada pagi hari sekitar pukul 6.30 WIB dan sore hari sekitar pukul 16.30 WIB.

Rata-rata hasil tangkapan kepiting bakau (Scylla spp.) setiap hari dengan jumlah alat tangkap sekitar 30 buah 3-8 ekor (4 kg per hari) dengan rata-rata bobot berkisar antara $350-450 \mathrm{~g}$.
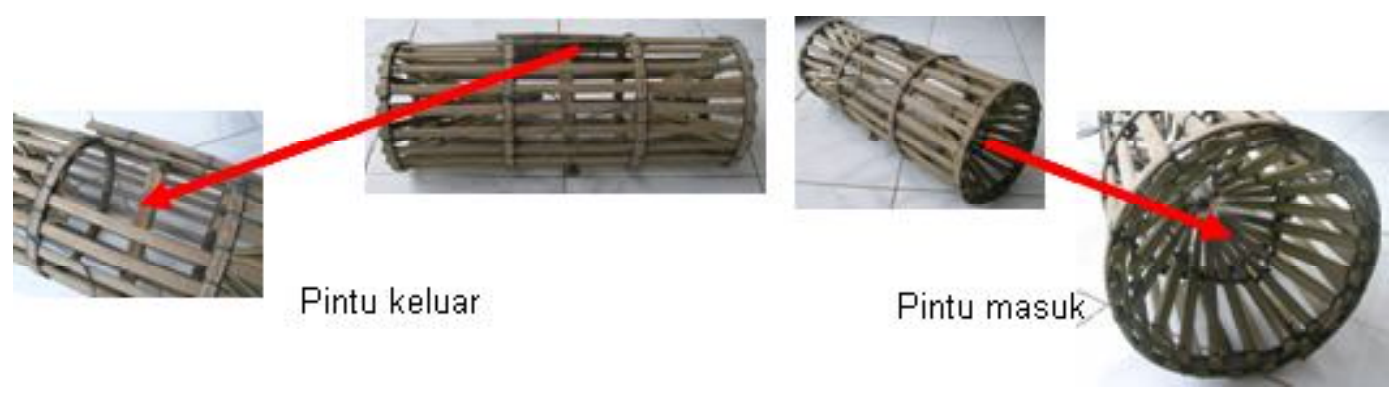

Gambar 2. Alat tangkap badong yang terbuat dari anyaman bambu.
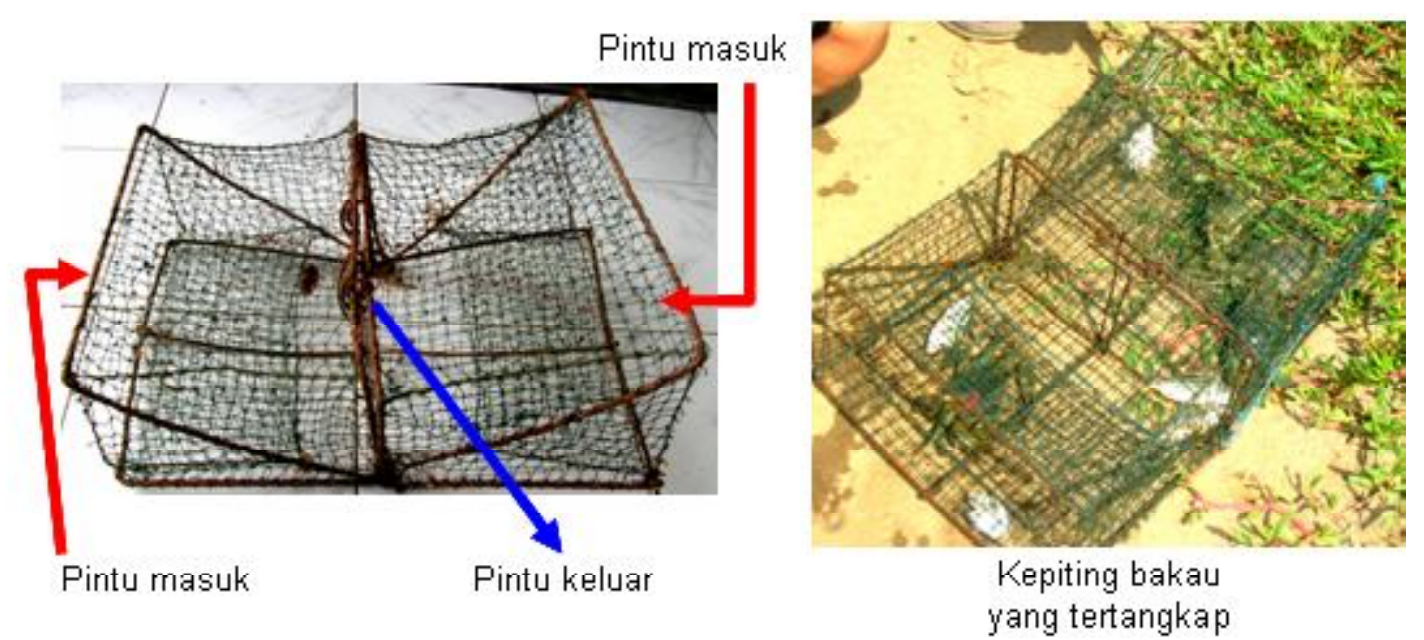

Gambar 3. Alat tangkap wadong yang terbuat dari kerangka kawat dan jaring (bubu lipat).

\section{Pancing}

Pancing adalah jenis alat tangkap untuk menangkap kepiting, yang terbuat dari batang kayu atau bambu dengan panjang $2 \mathrm{~m}$ dan dilengkapi dengan benang senar berukuran $\mathrm{D} 9$ dan nomor mata pancing no.12 (Gambar 4). Alat tangkap ini menggunakan umpan berupa ikan kecil. Untuk mengambil kepiting hasil tangkapan digunakan caduk atau serok yang terbuat dari jaring bertangkai kayu. Kepiting bakau yang tertangkap tidak tersangkut pada mata kail, namum hanya menggigit umpan sehingga 
cepat diambil dengan caduk. Pancing merupakan alat tangkap yang bersifat pasif di mana nelayan selalu berpindah-pindah tempat. Sebagian besar nelayan pancing mencari kepiting di perairan empang dan tambak. Penangkapan dilakukan pada siang hari mulai pukul 05.00-15.00 WIB, kepiting yang didapat setiap hari berkisar 4-10 ekor atau sekitar 5-10 kg.

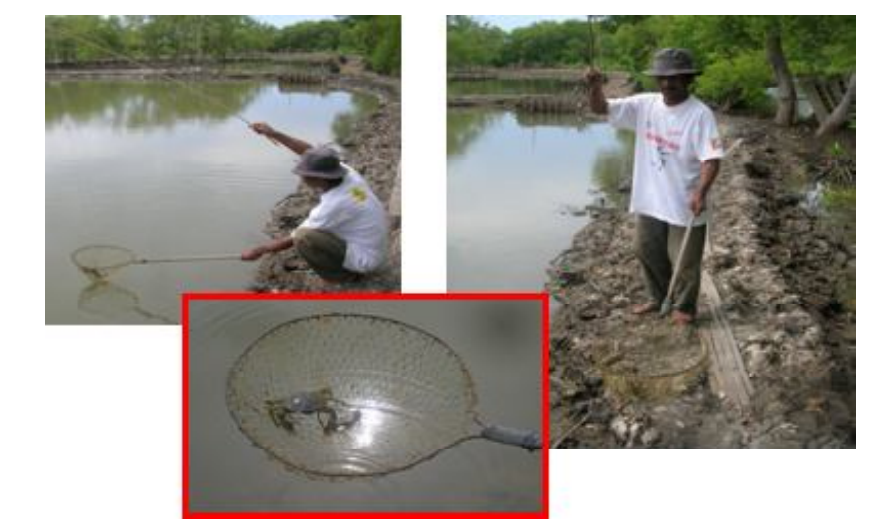

Gambar 4. Alat tangkap pancing yang dilengkapi caduk.

\section{Bangkol}

Bangkol merupakan alat tangkap yang bersifat aktif. Menurut Hideaki dalam Ayodyoa (1981) dan Sudirman \& Mallawa (2000), teknik penangkapan dengan mengait lalu menangkap. Alat ini terbuat dari kayu sebagai tangkai dan besi yang dilengkungkan yang berfungsi untuk mengait kepiting yang tersembunyi dalam lubang di sepanjang pematang tambak dan empang (Gambar 5). Dalam beroperasi, seorang nelayan membawa bangkol dalam berbagai ukuran panjang sesuai dengan jarak tempat berdiri dengan lubang kepiting. Kepiting yang tertangkap oleh alat ini berukuran lebih besar dibanding alat tangkap lain. Waktu mencari kepiting siang hari dari pukul 08.00-15.00 WIB. Nelayan dengan alat tangkap ini tidak dapat beroperasi setiap hari, namun sekitar 3 hari sekali. Tujuannya adalah untuk memberikan kesempatan pada lubang kepiting agar terisi kembali. Setiap kali beroperasi nelayan mendapatkan kepiting sekitar 6-8 ekor dengan bobot total berkisar 5-7 kg.

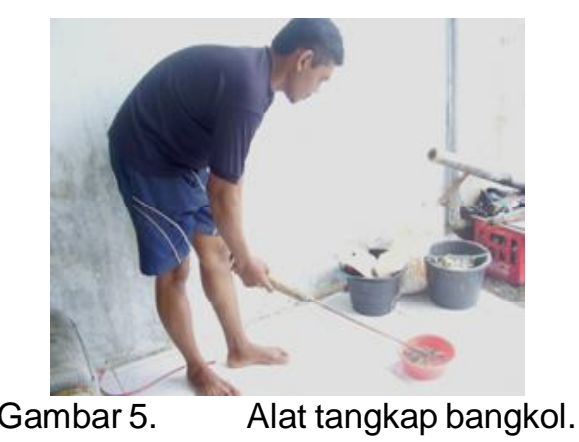

\section{KESIMPULAN}

Alat tangkap yang digunakan oleh nelayan di Desa Mayangan merupakan alat tangkap tradisional. Alat tangkap tersebut terbagi 2 kelompok yaitu alat tangkap pasif yang terdiri atas badong $4 \mathrm{~kg}$ dengan ukuran antara 350-450 g, pancing 5-10 kg dan bangkol jumlah yang tertangkap 5-7 kg.

\section{DAFTAR PUSTAKA}

Syam, A. R., Sulistiono, \& S. E. Purnamaningtyas. 2007. Laporan Survei Trip I: Pemacuan Stok Kepiting Bakau (Scylla spp.) di Pantai Utara Jawa. Loka Riset Pemacuan Stok Ikan. Jatiluhur (belum diterbitkan).
Ayodhyoa, A. U. 1981. Metode Penangkapan Ikan. Yayasan Dewi Sri. Bogor.

Sulistiono, S. Watanabe, \& S. Tuchida. 1994. Biology and Fisheries of Crab in Segara Anakan Lagoon in Ecological Assesment for Management Planning of Segara Anakan Lagoon Cilacap, Central Java (eds F. Takahima \& K. Soewardi). p. 65-76. Nodai University of Agriculture JSPS-DGHE Program. DOHM Press. Tokyo. Japan

Sudirman \& A. Mallawa. 2000. Teknik Penangkapan Ikan. Rineke Cipta. Jakarta. 